\title{
Of Museums and Digital Culture: A landscape view
}

\author{
Tula Giannini \\ Professor of Information \\ School of Information \\ Pratt Institute \\ New York, USA \\ http://mysite.pratt.edu/ giannini/ \\ giannini@pratt.edu
}

\author{
Jonathan P. Bowen \\ Professor of Computing \\ School of Engineering \\ London South Bank University \\ London, UK \\ http://www.jpbowen.com \\ jonathan.bowen@Isbu.ac.uk
}

\begin{abstract}
A book on Museums and Digital Culture, edited by the two authors of this paper, is planned for publication in 2019. The book is structured in ten parts, typically with around three contributed chapters in each part. This paper will survey each of these areas to provide a landscape view of the overall topic, together with some personal conclusions and views on future directions by the authors. What distinguishes this museum book from others, is its focus on digital culture and art, digital behaviour, and the interaction of real and virtual life, and how this increasingly impacts museums as they move into the future. We trace the development of digital culture from its foundations in the 1940 s with the work of Shannon, inventor of information theory and Turing, father of computer science, to present. A key concept is to bring diverse perspectives and voices on the 21st century museum, from inside and beyond the museum walls, of artists, academics, and professionals, as museums transform into the digital future.
\end{abstract}

Archives. Digital art. Digital culture. Digital heritage. Exhibitions. GLAM. Libraries. Museums. Philosophy. Strategy.

\section{BACKGROUND}

l'm going online

taking the onramp to digital life

at the intersection of the web and Internet

don't forget

I see you

But we've ever met

Exiting at the museum stop

No more bits and bots

No Google maps or apps

As I transition from virtual life

to reality

I enter a gallery

$A$ visitor in a foreign land

Cell phone still in hand

- T. Giannini (2018)

The digital world is full of dubious and ephemeral material, much of it dubbed "fake news" by some people. On the other hand, museums are institutions that have much worthwhile content and stories based around their collections. The Internet and web have been and will continue to be a wonderful resource for outreach from museums into the world, without geographical boundaries. Museums are now part of the digital culture of everyday life. With this in mind, a new book (Giannini \& Bowen 2019) is planned to cover the interleaving of museums and digital culture with respect to a number of different aspects and viewpoints.

\section{OVERVIEW OF THE BOOK}

This proposed book (Giannini \& Bowen 2019) will offer new perspectives and research on how digital culture is transforming museums in the $21^{\text {st }}$ century as they strive to keep pace with emerging technologies driving cultural and social change played out not only in today's pervasive networked environment of the Internet and specifically the web, but also in everyday life, from home to work and on city streets (Giannini \& Bowen 2016; 2017). In a world where digital culture has redefined human information behaviour as life in code and digits, increasingly it dominates human activity and communication. These developments have radically changed the expectations of the museum visitor, real and virtual, the work of museum professionals and, most prominently, the nature of the museum exhibition. Museums have become porous, interacting with their environments and living beyond 
their walls in both physical and digital worlds. Taking this as a starting point, the editors frame the discussion broadly while individual contributors provide varied viewpoints from their own experiences, expertise, practice, and research.

Overall, this book aims to create a new picture of the $21^{\text {st }}$ century museum field. As museums become shared spaces with their communities, local, national and global, as they move from collectioncentred to user/visitor-centred institutions, they are assuming changing roles and responsibilities tied to new goals for engaging their audience, conveying meaning through collections, creating learning experiences and, importantly, connecting to daily digital life and culture, integral to the museum ecosystem.

Studies of recent exhibitions at museums leading change are used to exemplify new directions while they point to a new vision for the museums of the future at the heart of which is the integration of digital interaction, visitor participation, and the merging of physical and digital space.

Having surveyed previous books on digital aspects of museums and culture (Parry 2007; Tallon \& Walker 2008; Parry 2010; Bowen et al. 2013; Buatista 2013; Legêne \& van den Akker 2017; Vermeeren et al. 2018), this planned book is distinguished by its focus on the impacts of the world it serves that is in a digital moment of rapid social and cultural change. The museum as it is defined today is essentially a $19^{\text {th }}$ century institution that embodies $19^{\text {th }}$ century aesthetics and values. When the look and feel of museum galleries in $19^{\text {th }}$ century mode remains static, they increasingly seem dusty, lacking new thought and dynamic energy, symbols of a past in search of new way of conveying meaningful narrative. So, while other books are considering museums from the inside (administration, management, process, collections, etc. - in essence, the traditional departments), our book considers museums from the vantage point of inside/outside interaction, participation, and collaboration. This porous flexible model enables new ideas and change, breaking out of the established silos of past practice.

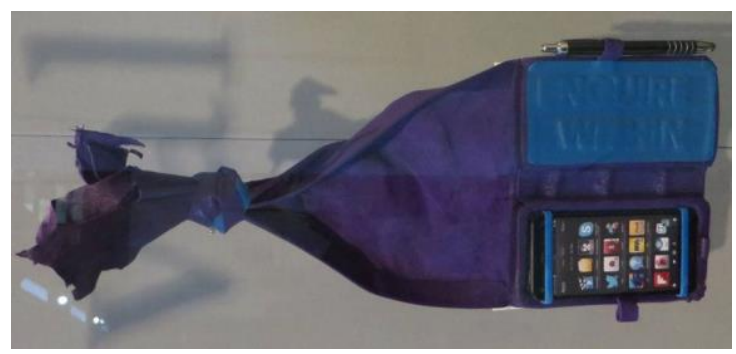

Figure 1: 'Enquire Within” by Jill Lauriston. Artwork reimagining the book in the digital age, exhibited at the Weston Library, Oxford, 2017. (Photograph by Jonathan P. Bowen.)
We will feature case studies through the lens of artists (e.g., see Figure 1), exhibitions, and gallery design/architecture - both physical and virtual. The book will create a body of new evidence - so not adopting a didactic approach, but rather one that inspires the reader to look at and think about the new evolving museum landscape and its diverse communities.

The editors intend to draw on EVA London Conference/Symposium speakers and papers as a starting point for some chapters (Giannini \& Bowen 2016; 2017).

\section{THEMES}

\subsection{Introduction}

We trace the foundations of digital culture to Shannon and Turing, pioneers of information theory and computer science including algorithms, machine-learning and artificial intelligence, and show how these developments are shaping our digital way of life at present and in the future. We examine digital life in the context of digital ways of doing, knowing, being, and living, and cover, for example, digital information behaviour and the impacts of the convergence of all digital media, a digital tipping point at the heart of digital culture. We see that since our paper, Digitalism: The New Realism (Bowen \& Giannini 2014), the trends noted then such as digitisation, digital information and communication behaviour, and the ubiquitous use of smart phones have only intensified and more than ever pose challenges to GLAM institutions as visitors and users become empowered as participants. Where feasible, the public has had an almost universal uptake of digital devices for communication and information, including search, sending and receiving messages, interaction through social media, digital expression, publishing on the web and creating online identities shared through personal websites and blogs.

Social and cultural change, social justice and political movements, are being propelled by the digital revolution which gives voice to communities and individuals empowered by digital forms of expression as full-fledged digital participants. They share their thoughts and creative works through social media, e-messaging, blogs, websites and YouTube, living in a digital world where access to information and communication via the web and Internet is available 24/7. Museum audiences are using new and powerful ways to engage online. For example, they can explore collections, view exhibitions and video presentations and plan onsite visits. As we take flight into cyberspace, physical space and the human interface are merging with artificial life and the Internet of Things (IOT). We 
cannot but marvel at the genius of Shannon and Turing who gave us not only the science and technology of what is now our future, but as well the vision that shapes it.

\subsection{Philosophy and Theory}

We consider the ideas behind $21^{\text {st }}$ century museums, in the context of digital arts and digital humanities, from a philosophical viewpoint (Polmeer 2016). This includes interactive digital art, installation and mixed-media art, participatory and interactive art and exhibitions and the digital technology and tools that create and support it.

Digital life, like digital art, underlies a powerful philosophical shift in the way museums are interpreting anew their societal roles and responsibilities, and how they are reframing their communication modes and relationships with their audiences and general public. Aligning with today's digital culture facilitated by the Internet, web, and social media, museums are adopting the overarching principles of a democratic society as they prioritise participation, inclusiveness, diversity and social justice. This is causing sweeping changes as museums embrace diverse cultures, new forms of contemporary art, digital curation of collections shared online, with major museums such as the Metropolitan Museum of Art, the V\&A and the Getty, are taking the lead for open access and use of public domain works, whilst welcoming dialog and conversation with visitors.

Exhibitions, too, reflect our $21^{\text {st }}$ century humancentred philosophy that respects and accepts difference so that exhibition themes include topics on gender, homosexuality, feminism, radical viewpoints on identity, political and social movements, all of which find new interpretations in art and digital culture. The stayed, tradition of museology dominated by curatorial expertise and building collections that defined the museum of the pre-digital world, has given way to a new social framework where ideas, places, spaces and galleries are shared, and human experience and interaction with the arts take centre stage.

\subsection{Exhibitions}

We present evidence drawn from experience and data gathered as well as the literature - books and articles - over the past few years). Exhibitions, considered the centrepiece of the life of the museum, are increasing tied to the museum's digital life where most of museums' work and activities are carried-out and where art and information come together to convey content, meaning and narrative. We present a survey of exhibitions over the past few years by leading museums in New York and London to show new trends, innovative use of digital media technology, and an increasing presence of digital, installation and mixed media art. We juxtapose digital works exhibited inside and outside the museum and explore how the use digital displays across most sectors of society is influencing how the public views art which questions is very nature and meaning.

Museums are challenged by a new imperative to expand beyond their physical boundaries and connect with the public through digital media displays and activities that merge with the ubiquitous digital life of city streets and stores. As museum visitors move from outside into the physical space of the museum they bring with them their digital identity, information behaviour, and senses. Thus, museums are challenged to reinvent gallery space for $21^{\text {st }}$ century art creating the museum of the future.

\subsection{Exhibiting Permanent Collections and Digital Strategy}

An important current issue is how permanent exhibitions in museums are being updated to meet audience expectations. For example, at the Science Museum in London, the Information Age and Mathematics galleries have been redesigned, the latter by the leading architect Zaha Hadid, and the museum is in process of redoing the entire museum, stage by stage. To accomplish these goals, museums are developing a digital strategy applied across the entire museum. Generally, museum in $19^{\text {th }}$ and early $20^{\text {th }}$ century buildings are being challenged to find innovative way to reconceptualise their galleries and public space for the $21^{\text {st }}$ century.

The Victoria \& Albert Museum (V\&A) is another prime example with its new entrance and future museum in the east of London designed for the digital world. Conservation and preservation play a key role in the exhibition of permanent collections which consist of both objects on display and in storage, with the former the focus of condition analysis for which the use of digital technologies have become the methods of choice from digitisation, digital imaging, scanning, 3D printing, to scientific equipment such as spectroscopy, NMR and MIR. These technologies support the shift in conservation thinking, from invasive physical procedures to using digital techniques respect the documentary and historical status of an object. Digitisation is a primary tool for preservation and access and Google Cultural Institute and Lab for Art and Technology have focused their efforts on using high resolution photography to digitise museum collections in combination with virtual reality techniques to assist the museum community with providing online access and immersive user experiences with art and cultural heritage. 


\subsection{Museums on the web and Internet}

Museum websites, virtual museums, networks and platforms (APIs, interoperability, sharing collections, etc.) are an important aspect of the post-modern museum. It is worthwhile to take an analytic approach to the state of museum websites, identifying best examples, showing trends and user interactions, and evaluating effectiveness from data gathered such as Google analytics, level of access and use of collections, and issues such as copyright and intellectual property.

Museums today have a real presence in the digital world as they have made their websites important destinations for exploring collections, learning about museum activities and exhibitions. Many museums are offering online virtual tours of galleries, and shopping in museum stores. The Internet provides a place in cyberspace for virtual visitors to make real connections with the life of the museum, and for museums to collaborate and share collections using API technology. Digitisation of collections have lead the way in this area, and some museum are offering open access to this valuable resource. For example, the Metropolitan Museum provides open access to some 350,000 digitised art works. These efforts have proven to highly valuable to the work of academics and artists, and importantly is creating a global digital culture platform of highly curated and content and narrative that grows daily and can be accessed from anywhere in the world, a place that is open and free to virtual visitors, and inclusive of diverse cultures.

\subsection{Museum Audiences}

Real and digital interaction and participation are all important aspects to be considered by museums. Visitors/users empowered by digital technology, especially smartphones, have new expectations for engagement. There is a need for museums to convey meaning, engage visitors, and reflect social consciousness and awareness. Museums of any size must have programmes for outreach, diversity, inclusion and community interaction. Just as digital states of being and identity are changing visitor behaviour and expectations, they are in turn, recasting museum identity and states of being inside and outside the walls of the museum, as they open themselves to new ways of thinking about the world and its dynamic states of evolving social and cultural consciousness. As museums build relationships through social media they can find themselves more vulnerable to audience opinion and its relationship to art on display.

As a recent example, in December 2017, Mia Merill, visited the Metropolitan Museum and claimed that she was shocked upon viewing a 1938 painting by Balthasar, Thérese Dreaming, so much so, that she used Care2 Petition, an Internet site collecting almost 12,000 signatures for her demand that the Met remove the painting. The Metropolitan Museum's response was published quickly by the New York Times with the headline, "Met defends suggestive painting of girl after petition calls for its removal" (Libbey 2017). A statement from the Metropolitan Museum's chief communications officer, Ken Weine, focused on the museum/audience conversation saying that, "Moments such as this provide an opportunity for conversation, and visual art is one of the most significant means we have for reflecting on both the past and the present and encouraging the continuing evolution of existing culture through informed discussion and respect for creative expression." (Kinsella 2017).

The Manchester Art Gallery suffered a similar attack on its collections with the result being that "A celebrated painting JW Waterhouse [Hylas and the Nymphs] has been removed from display at the Manchester Art Gallery, in an act the museum says aims to "challenge this Victorian fantasy" of "the female body as either a 'passive decorative form' or a 'femme fatale"'." (Telegraph 2018). These examples demonstrate the power of social media's impact as it translates the US "MeToo" movement to the UK and beyond. What art works will be next in the public court of political correctness going viral? Will it be an Amedeo Modigliani painting of nude female body? Modigliani's painting pictured in Figure 2 sold for $\$ 170,405,000$ at a Christie's New York auction in November 2015 (Christie's 2015). If this work were publicly exhibited in the US, what would be the public's reaction?

In London, a major exhibition of the 2018 art season, is Tate Modern's comprehensive retrospective of Modigliani's work (Tate 2017), including a whole gallery of female nude paintings. The exhibition has also drawn attention due to its innovative use of Virtual Reality (VR) to recreate the artist's Paris studio to immerse the viewer more deeply in his art and life.

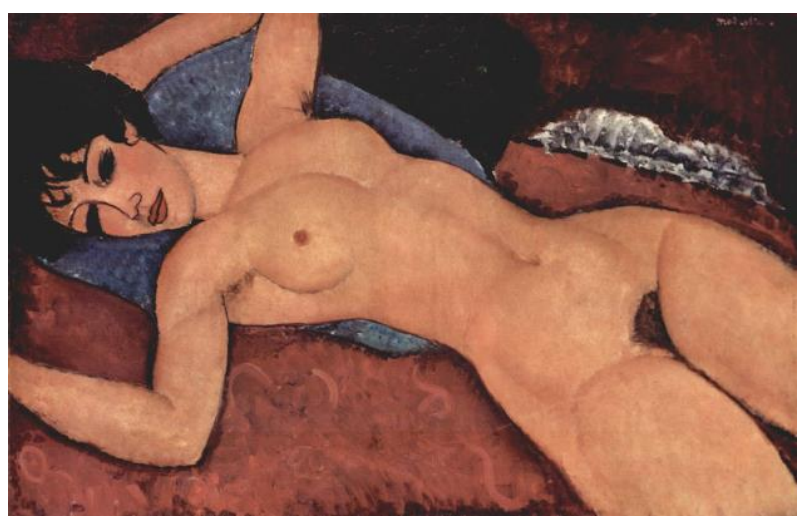

Figure 2: Amadeo Modigliani, Nu couché, 1917. (Wikimedia Commons.) 


\subsection{Digital Artists: Practice and Research}

Digital aesthetics and senses, installation, mixed media, interactive and participatory art, virtual reality, augmented reality, robots and robotics, and the impact of digital artists on the web, in their own voices, all impact on museums, and especially on art galleries. Increasingly, people are seeing digital as the world they inhabit is saturated with digital media. In 2017, Americans spent on average 12 hours per day of screen time. This immersion in digital media is affecting the human sense of colour, light, space, and time.

Digital art, and its frequent integration with installation and mixed media art, has achieved more prominence in museum exhibitions, especially museums of contemporary art. Extending its reach, digital art, especially on digital media screens are being featured in public spaces such as galleries, cultural institutions, departments stores, city streets, airports and train stations, so one is never far from seeing this versatile and growing art form. Digital art is expanding the definition of what is art, as it uses digital tools to make art in new ways making connections with contemporary social and cultural issues expressing topics of public interest.

\subsection{Education for Museum Professionals and Digital Artists}

Tula Giannini designed and introduced to Pratt School of Information three museum related programs, the first of their kind: Autumn 2015, a new museum master's program, Master of Science in Museums \& Digital Culture, that newly defines the knowledge and skill sets for $21^{\text {st }}$ century museum professionals through its cutting-edge curriculum and a new Advanced Certificate in Digital Curation and Preservation); Autumn 2008, a dual-master's degree, MS Library \& Information Science \& MFA Digital Arts, and Autumn 2008, an advanced Certificate in Museum Libraries.

The Brooklyn Visual Heritage website is currently hosted by Brooklyn Public Library. Pratt Institute, through the creative vision of the English artist Jeremy Gardiner, introduced the Institute's first Department of Digital Arts in the 1980s and which continues to present. Graduates in digital art can choose from an array of job opportunities taking advantage of the burgeoning digital life of New York City including hundreds digital design and user experience firms, galleries, museums, film and recording studios, archives, and the preforming arts.

Some projects funded by the US Institute of Museum and Library Services (IMLS) have focused on digitisation, access and preservation, and collaboration within and across cultural institutions. For example, Project CHART (Cultural Heritage,
Access, Research and Technology), was a collaboration between four cultural institutions whereby Pratt students enrolled in a new digital cultural heritage program introduced by Giannini, were mentored by professional staff to produce the Brooklyn Visual Heritage website (see Figure 3). The site is maintained today by the Brooklyn Public Library providing seamless search to access the historic photography collections of the Brooklyn Museum, Brooklyn Historical Society and Brooklyn Public Library. The project team used data analytics, usability testing, a blog and social media to guide the design and experience of the site.

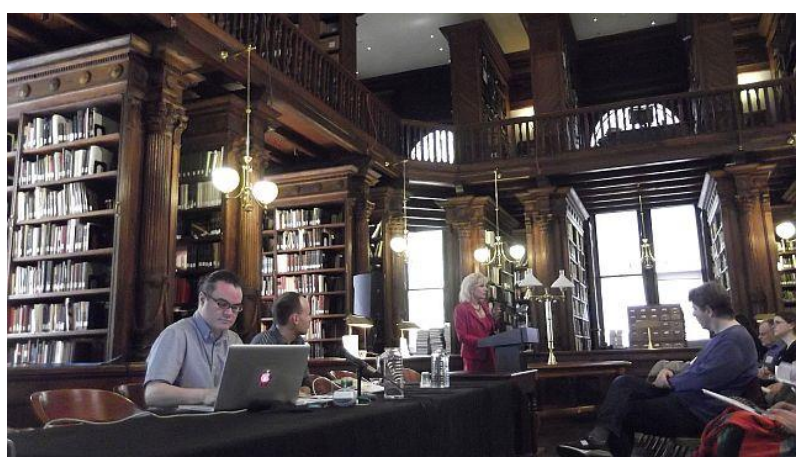

Figure 3: Project CHART Symposium at the Brooklyn Historical Society, May 2015 Pictured are Seb Chan and Tula Giannini.

(Photograph by Jonathan P. Bowen.)

\subsection{Museum Libraries and Archives}

Among the world's finest art libraries are those housed in museums. Some perfect examples of this are found prominently in New York City where we find the Watson Library and several other specialised libraries at the Met, the Frick Art Reference Library, part of the Frick Museum, and the Morgan Library with its dazzling new public space designed by Renzo Piano. These libraries, including special and archival collections, rare books and ephemera constitute a treasure trove of materials on art, design and architecture, and importantly, their collections in general have been developed around subject areas of the museum's object collections. Further, the Metropolitan Museum, Frick, and Morgan have conservation laboratories, provide public access and services, and support scholarly research on topics relevant to the collections.

Museum libraries provide internships to students who wish to pursue career in museums and libraries and Pratt's fellowship program, designed and introduced by Giannini, supports students for a twosemester fellowship at these institutions and several others including the Guggenheim, Whitney, American Museum of Natural History, and Brooklyn Historical Society. Significantly, museums exhibitions are more than ever incorporating archival material to add context and information. For 
example, the recent exhibition on opera performance at the V\&A drew heavily on such materials including music scores and recordings, letters of composers, photographs of performers, posters and set designs and costumes.

The importance of collaboration between museums and their libraries and archives for communicating narrative and meaning to visitors is generally overlooked although they can make critical connections between art and information. Looking to the future, as museums take full advantage of digital assets and methods for public interaction, the need for collaboration will grow. Significantly, museum libraries were early adopters of digitising their collections to improve access and use, so that their substantial digital assets of rare and primary materials illuminating collections can now be used in new creative ways.

\subsection{Envisioning the Digital Future of Museum}

We consider the growing forces competing with museums for audience: entertainment - global media - 2.2 billion Facebook users - and the many hours people spend each day with digital media. Added to this, artists across disciplines are using the Internet to create their own identities and communicate art works, and design exhibitions and shows that often occupy physical and digital space, whilst museums have long identified with their physical space as a specific place in time and space, have now expanded to cyberspace, having a digital identity on the web. Thus, In the digital world, artists can tell their own story and create identity, bypassing the traditional gatekeepers. How should artists and museums relate to one another?

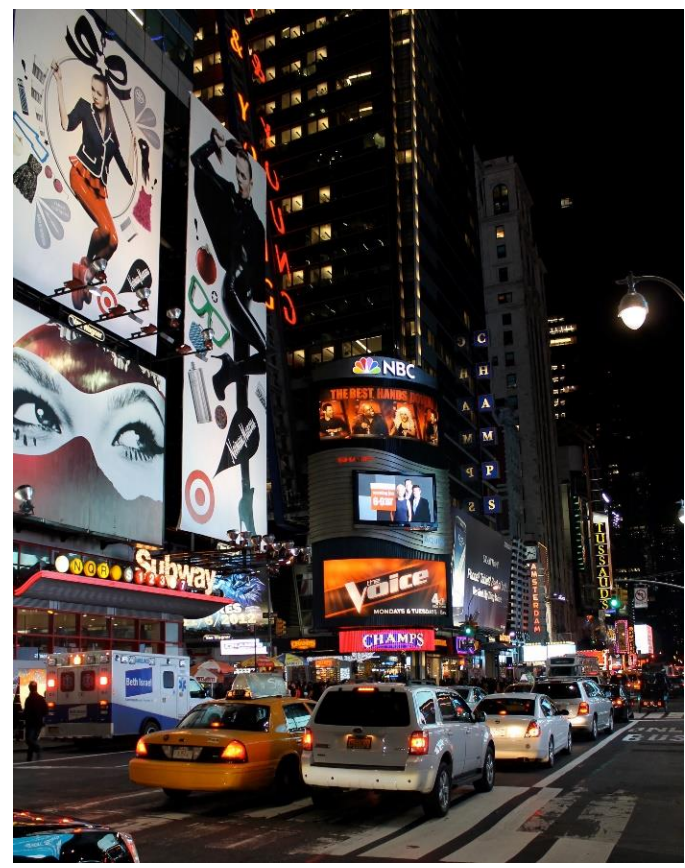

Figure 4: Times Square at night, New York City, 2012. (Wikimedia Commons.)
Times Square, New York City (see Figure 4), captures an aspect of the museum digital dilemma, as museums find themselves trying to compete with digitally designed spaces - department stores, street art, digital media displays and public art and entertainment.

$21^{\text {st }}$ century museums by definition reside in the digital culture ecosystem and thus are in search of a new identity as they grapple with audience perceptions of the past and the promise of the future. Future challenges can be seen in:

- Balancing physical and digital reality of space and time.

- Beyond the walls - the impact of social and cultural trends and questions of human identity

- Battle of museum insiders and outsiders

- From protected spaces to common places where will the museum reside

- is visitor experience enough - will museums be a new type of "Disneyland."

- As museums strive to create a new model for the complex digital world, no one answer will be the solution.

- Baking a new museum cake - what will be the ingredients?

Museums are facing new challenges as new digital reality dominates human attention and existence. Looking out from within the museum, the insiders, the museum professionals, are thinking about what their museum should be or become. Outside, the world is speeding towards a dynamic synergy of physical and virtual life marked by rapid transformation and new states of being. This means that museums remaining the same, not changing, will fall behind, appearing old and dusty. Who will come to a quiet place of yesteryear? Central to finding a new sense of identity that seems relevant, contributes to social and cultural advancement, and enriches people's lives by being part of their future, is not a question at all, but a necessity and imperative. The new directions museums will take will be mostly determined by what is happening and developing outside - the social issues, how artists are seeing and making art, how people are responding to new cultural forms and expressions, and how they are living, communicating and working.

Museums have no choice but to be in this world of making changes rapidly in order to maintain strong ties and connections to their audience, actual and potential, real and virtual. As computational culture causes radical change, it is creating a digital ecosystem where art and culture is everywhere and everyone - in every click in multiple forms across the Internet and social media. This complex, diverse digital ecosystem invites all participants to its 
democratic platform. Everyone who wishes to be, is a player, has a voice and speaks across digital media in an endless array of messages, blogs and websites, as they share stories, likes, opinions and ideas. How will museums assert a newly envisioned identity while being an integral part of daily digital happening and how will they position themselves in a growing network of cultural identities, find friends and collaborators and be in conversation with other cultural institutions and communities. Museums have moved from being quiet, highly organised and predictable institutions; they are transforming into complex cultural organisms entrenched in the life of diverse communities and connected to global platforms.

Museums of the future will communicate in many languages, have public conversations, tell stories, create experiences, collaborate with other museums, with artists of all types and with the public, show process and pose questions, while relinquishing their long-standing role of unchallenged expertise, to one of sharing the stage with other actors, and addressing issues of an open museum that embraces the digital future. For example, at the British Museum, half of the electronic guide usage is already in Mandarin.

The year 2017 will stand out for the significant impact the \#MeToo-Time's-up movement continues to exert on museums as individual artists and their works are being challenged for being part of the culture of abuse of women, sparking exhibition cancellations, removal of art works and protests by performance artists, most prominently by Emma Sulkowicz's performances at the Metropolitan Museum and MoMA prompting the Met's chairman for modern and contemporary art to state: "If we only see abuse when looking at a work of art, then we have created a reductive situation in which art is stripped of its intrinsic worth - and which in turn provokes the fundamental question of what the museum's role in the world should be." (Cascone 2018). This indeed is relevant to both the role and identity of museums facing a new social order revisioning public space and the space between museum and audience as they evolve as creative participatory spaces of conversations, relationships and interdependent roles that equally reflect the expectations and identities of both sides of the institutional equation.

\section{CONCLUSION}

We have entered the next wave of the digital revolution as all media has gone digital (Parry 2013), a state of being that closely aligns with human creativity and innovation - mainly, art, culture and the humanities, the lifeblood of the museum. The convergence of media as digital, which makes all media equally usable, is fueling the rise of human expression through visual and sound media, as we shift to a post-text-dominated era to life on the Internet obsessed with YouTube, podcasts, video, and images, while new technology is introduced regularly such as Google Lens for smart phone visual recognition using Al. This trend reveals the power of visual and sound media as digital media language that enables museums to reach larger more diverse audiences.

Indeed, information and communication technology (ICT) research has become the engine of change positioned at the heart of the museum, while empowering interaction of individuals and institutions across the globe. Although the digital shift represents major challenges to the museum of the future, meeting these challenges will depend on how museums integrate into the digital ecosystem and use emerging technologies, whilst recognising the power of digital culture to transform human identity, behavior, states of being, digital seeing, art and aesthetics. Museums too are transforming. With altered states being and a new sense of identity, they enter the digital future.

\section{Acknowledgement}

Jonathan Bowen is grateful to Museophile Limited for financial support.

\section{REFERENCES}

Beazley, I., Bowen, J. P., McDaid, S., and Liu, A. H.-Y. (2010) Dulwich OnView: An art museum-based virtual community generated by the local community, In A. Seal, J. P. Bowen, \& K. Ng (eds.), EVA London 2010 Conference Proceedings. BCS, Electronic Workshops in Computing, pp. 79-86.

http://ewic.bcs.org/content/ConWebDoc/36053

Borda, A. and Bowen, J. P. (2017) Smart cities and cultural heritage - A review of developments and future opportunities. In Bowen et al. (2017), pp. 9-18. DOI: 10.14236/ewic/EVA2017.2

Bowen, J. P., Bennett, J., and Johnson, J. (1998) Virtual visits to virtual museums. In MW98: Museums and the Web 1998, Toronto, Canada, 22-25 April. Archives \& Museum Informatics.

http://www.museumsandtheweb.com/mw98/papers/bowen/bowen paper.html

Bowen, J. P., Bennett, J., Borda, A., Hodges, A., Filippini-Fantoni, S., and Beler, A. (2005) The development of science museum websites: Case studies. In L. T. W. Hin and R. Subramaniam (eds.), Elearning and Virtual Science Centers, Section 3: Case Studies, Chapter XVIII, pp. 366-392. Idea Group Publishing.

Bowen, J. P., Diprose, G., and Lambert, N. (eds.) (2016) EVA London 2016: Electronic Visualisation and the Arts. BCS, Electronic Workshops in Computing (eWiC). http://www.bcs.org/ewic/eva2016 
Bowen, J. P., Diprose, G., and Lambert, N. (eds.) (2017) EVA London 2017: Electronic Visualisation and the Arts. BCS, Electronic Workshops in Computing (eWiC). http://www.bcs.org/ewic/eva2017

Bowen, J. P. and Giannini, T. (2014) Digitalism: The new realism? In $\mathrm{K}$. Ng, J. P. Bowen, and S. McDaid (eds.), EVA London 2014: Electronic Visualisation and the Arts. BCS, eWiC, pp. 324-331. DOI:

10.14236/ewic/eva2014.38

Bowen, J. P. and Giannini, T. (2015) Galois connections: Mathematics, art, and archives. In K. Ng, J. P. Bowen, \& N. Lambert (eds.), EVA London 2015: Electronic Visualisation and the Arts. BCS, Electronic Workshops in Computing, pp. 176-183. DOI: 10.14236/ewic/eva2015.18

Bowen, J. P. and Giannini, T. (2016) From analogue to digital in literature and art. In Bowen et al. (2016), pp. 1-4. DOI: $\underline{10.14236 / \mathrm{ewic} / \mathrm{EVA2016.1}}$

Bowen, J. P., Keene, S., and Ng, K. (eds.) (2013) Electronic Visualisation in Arts and Culture. Springer, Series on Cultural Computing.

Buatista, S. S. (2013) Museums in a Digital Culture. AltaMira Press.

Cascone, S. (2018) Artist Emma Sulkowicz wore asterisks-and little else-to protest Chuck Close at the Met (and Picasso at MoMA). Artnet News, 2 February. https://news.artnet.com/art-world/emma-sulkowiczperformance-protest-1214429

Christie's (2015) Modigliani's Nu couché (Reclining Nude) leads a night of records in New York. Christie's Daily, 10 November.

http://www.christies.com/features/Modigliani-Nu-coucheReclining-Nude-leads-a-night-of-records-in-New-York-6782$\underline{\text { 3.aspx }}$

Filippini-Fantoni, S. and Bowen, J. P. (2008) Mobile multimedia: Reflections from ten years of practice. In Tallon and Walker (2008), pp. 79-96.

Gannis, C. (2017) The augmented selfie. In Bowen et al. (2017), pp. 319-326. DOI:

\subsection{6/ewic/EVA2017.66}

Giannini, T. and Bowen, J. P. (2014) The Brooklyn Visual Heritage website: Brooklyn's museums and libraries collaborate for Project CHART. In MW2014: Museums and the Web 2014, Baltimore, USA, 2-5 April. http://mw2014.museumsandtheweb.com/paper/thebrooklyn-visual-heritage-website/

Giannini, T. and Bowen, J. P. (2015) A New York Museums and Pratt partnership: Building Web collections and preparing museum professionals for the digital world. In MW2015: Museums and the Web 2015, Chicago, USA, 8-11 April.

http://mw2015.museumsandtheweb.com/paper/a-new-yorkmuseums-and-pratt-partnership-building-web-collections-andpreparing-museum-professionals-for-the-digital-world/

Giannini, T. and Bowen, J. P. (2016) Curating digital life and culture: Art and information. In Bowen et al. (2016), pp. 237-244. DOI:

10.14236/ewic/EVA2016.46
Giannini, T. and Bowen J. P. (2017) Life in Code and Digits: When Shannon met Turing. In Bowen et al. (2017), pp. 51-58. DOI: 10.14236/ewic/EVA2017.9

Giannini, T. and Bowen, J. P. (eds.) (2019) Museums and Digital Culture: New perspectives and research. Series on Cultural Computing. Springer. (To appear.)

Kinsella, E. (2017) The Met says 'suggestive' Balthus painting will stay after petition for its removal is signed by thousands. Artnet News, 5 December. https://news.artnet.com/art-world/met-museum-responds-topetition-calling-for-removal-of-balthus-painting-1169105

Legêne, S. and van den Akker, C. (2017) Museums in a Digital Culture: How art and heritage become meaningful. Amsterdam University Press.

Libbey, P. (2017) Met defends suggestive painting of girl after petition calls for its removal. The New York Times, 4 December.

https://www.nytimes.com/2017/12/04/arts/met-museum-balthuspainting-girl.html

Lomas, A. (2016) Species Explorer: An interface for artistic exploration of multi-dimensional parameter spaces. In Bowen et al. (2016), pp. 95-102. DOI: 10.14236/ewic/EVA2016.23

Papadimitriou, I., Addis, J., Lomas, A., Dekker, L., Singporewaia, K., and Tresset, P. (2017) Digital Futures: Lumen Big Reveal. In Bowen et al. (2017), pp. 438-440. DOI: $10.14236 /$ ewic/EVA2017.86

Parry, R. (2007) Recoding the Museum: Digital Heritage and the Technologies of Change, Routledge.

Parry, R. (2010) Museums in a Digital Age, Routledge.

Parry, R. (2013) The end of the beginning: Normativity in the postdigital museum. Museum Worlds, 1, pp. 2439. DOI: $10.3167 /$ armw.2013.010103

Polmeer, G. (2016) Sublating time: Hegel's speculative philosophy and digital aesthetics. In Bowen et al. (2016), pp. 257-264. DOI:

10.14236/ewic/EVA2016.49

Soni, J. and Goodman, R. (2017) A Mind at Play: How Claude Shannon Invented the Information Age. Simon \& Schuster

Tallon, L. and Walker, K. (eds.) (2008) Digital Technologies and the Museum Experience. AltaMira.

Tate (2017) Modigliani. Tate Modern, London, 23 November 2017 - 2 April 2018.

http://www.tate.org.uk/whats-on/tate-modern/exhibition/modigliani

Telegraph (2018) Manchester Art Gallery's \#MeTooinspired removal of nude Nymphs painting branded a 'pathetic stunt'. The Telegraph, 1 February.

https://www.telegraph.co.uk/art/what-to-see/manchester-artgallerys-metoo-inspired-removal-nude-nymphs-painting/

Twenge, J. M. (2017) Have smart phones destroyed a generation? The Atlantic, September.

https://www.theatlantic.com/magazine/archive/2017/09/has-thesmartphone-destroyed-a-generation/534198/

Vermeeren, A., Calvi, L., Sabiescu, A. (eds.) (2018) Museum Experience Design. Springer, Series on Cultural Computing. 